\title{
Postup vyhodnocení odtokových poměrů a stanovení návrhových průtoků v projektu Strategie ochrany před negativními dopady povodní a erozními jevy př́rodě blízkými opatřeními v České republice
}

\section{MARTIN STEHLÍK, MARTIN PAVEL, VLADIMÍR BURIAN}

Klíčová slova: odtokové poměry - čísla odtokových křivek - kritické body - vodní nádrže - srážkoodtokové modelování

\section{SOUHRN}

Projekt Strategie ochrany před negativními dopady povodní a erozními jevy prírodě blízkými opatřeními v České republice reší komplexně možnosti zvýšení retence vody v krajině. Př́ispěvek stručně popisuje dva z nástrojů pro analýzy a návrhy: použití metody CN křivek a srážkoodtokové modelování.

\section{ÚVOD}

Jedním ze stěžejních cílů projektu Strategie ochrany před negativními vlivy povodní a erozními jevy prírodě blízkými opatřeními v ČR je snížení výšky př́mého odtoku při prívalových srážkách, popř. transformace povodňových vin $\checkmark$ nádržích. Na základě analýz současného stavu odtokových poměrů byly identifikovány problematické oblasti, ve kterých byl navržen soubor opatření a posléze posouzena jeho efektivita.

\section{ANALÝZA ODTOKOVÝCH POMĚRŮ}

Vyhodnocení odtokových poměrů v povodích ČR před návrhy opatření spočívalo ve vytvoření gisových vrstev hodnot CN (čísla odtokových křivek), směrů odtoku a akumulace odtoku. Dále byla vyhodnocena potenciální retence A (mm), výšky prímého odtoku Ho $(\mathrm{mm})$ a objemy prímého odtoku Oph $\left(\mathrm{m}^{3}\right)$ při návrhových srážkách pro povodí III. a IV. rádu. Tím byly připraveny podklady pro návrhy retenčních prostor, vyhodnocení změn odtokových poměrů po návrzích opatření a podklady pro detailní posouzení efektů navržených opatření.

K určení možné retence území byly využity vrstvy CN hodnot ve třech stupních předchozího nasycení povodí. Pro území ČR byla vytvořena souvislá vrstva způsobu využití území, jejímž základem byla geodatabáze půdních bloků LPIS rozšiřená o vrstvu PUPFL (pozemky určené pro plnění funkce lesa) a doplněná daty ze ZABAGEDu. Vrstva způsobu využití území byla prolnuta s vrstvou hydrologických skupin půd.
Konkrétní hodnoty pro výchozí vrstvu CN II (střední stupeň nasycení) jsou obsaženy v tabulce 1. Pro ornou půdu byly hodnoty CN rozlišeny pro dvě varianty: detail a povodí. Pro variantu detail byly použity poměrně vysoké hodnoty (možnost souběhu nepříznivých osevních postupů na celém povodí) a tato varianta je využívána pro analýzy malých povodís plochou do $10 \mathrm{~km}^{2}$. Pro variantu povodí byla hodnota CN snižena - odpovídá prưměru pro širokořádkové plodiny a úzkořádkové plodiny.

Tabulka 1. Hodnoty CN II pro jednotlivé způsoby využití území a hydrologické skupiny půd (HSP)

Table 1. Values of CN II for different land-use and hydrological soil groups (HSP)

\begin{tabular}{|c|c|c|c|c|c|c|}
\hline \multirow{2}{*}{ Využití území } & \multirow{2}{*}{ Zkratka } & \multicolumn{5}{|l|}{ HSP } \\
\hline & & A & B & C & D & $\mathbf{N}$ \\
\hline LPIS - orná půda (detail) & $\mathrm{Rd}$ & 72 & 81 & 88 & 91 & 83 \\
\hline LPIS - orná půda (povodí) & $\mathrm{Rp}$ & 68,5 & 78,5 & 86 & 89,5 & 80,5 \\
\hline LPIS - chmelnice & C & 72 & 81 & 88 & 91 & 83 \\
\hline LPIS - vinice & V & 59 & 74 & 82 & 86 & 72 \\
\hline LPIS - ovocný sad & $\mathrm{S}$ & 59 & 74 & 82 & 86 & 72 \\
\hline LPIS - travní porost & $\mathrm{T}$ & 49 & 69 & 79 & 84 & 70 \\
\hline LPIS - jiná kultura & $\mathrm{O}$ & 59 & 74 & 82 & 86 & 72 \\
\hline LPIS - rybník & B & 100 & 100 & 100 & 100 & 100 \\
\hline LPIS - zalesněno & $\mathrm{L}$ & 45 & 66 & 77 & 83 & 67 \\
\hline les-porost & LPOR & 36 & 60 & 73 & 79 & 62 \\
\hline silnice, dálnice & SIL & 74 & 84 & 90 & 92 & 85 \\
\hline vodní plocha & VPL & 100 & 100 & 100 & 100 & 100 \\
\hline ostatní & OST & 59 & 74 & 82 & 86 & 72 \\
\hline
\end{tabular}

N... hydrologická skupina půd neurčena 
Hodnoty uvedené v tabulce jsou platné pro střední stupeň Indexu předchozích srážek (IPS II). IPS je určován na základě 5 denního úhrnu předcházejících srážek. IPS I je "suchý“ a určuje stav, který ještě umožňuje uspokojivou orbu a obdělávání (kumulativní úhrn srážek za 5 dní dosáhl méně než $36 \mathrm{~mm}$ ). IPS II je „Střední" a bývá uvažován pro návrhové účely (kumulativní úhrn srážek za 5 dní dosáhl 36 až $53 \mathrm{~mm}$ ). IPS III je „mokrý“ a vyjadřuje stav přesycení předcházejícími dešti (kumulativní úhrn srážek za 5 dní dosáhl více než 53 mm).

Hodnoty CN I (pro IPS I) a CN III (pro IPS III) byly odvozeny na základě hodnot CN II v prostředí ArcGIS Raster Calculator podle vzorců uváděných Janečkem a Kovářem [1]:

- CN I = CN II / (2,334-0,011334 CN II),

- CN III = CN II / $(0,4036+0,005964$ CN II).

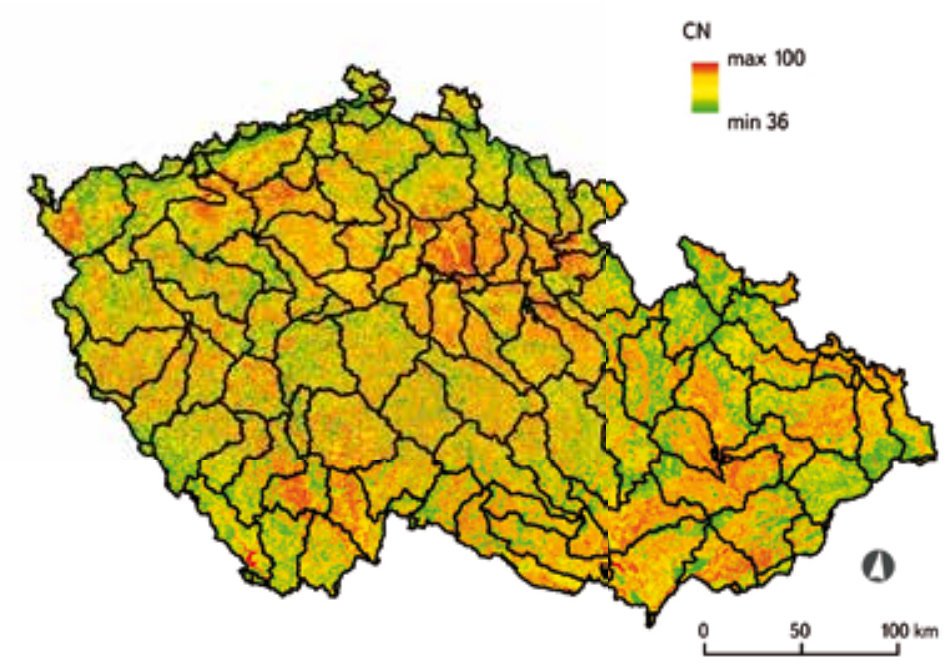

Obr. 1. Hodnoty CN II ve variantě „detail“ u orné půdy

Fig. 1. CN II values in a variant "detail" by arable land

Na základě porovnání objemů prímého odtoku pro současný stav využití území s objemy prímého odtoku pro návrhový stav s protierozními opatřeními v jednotlivých povodích Ize stanovit, jaký mají navrhovaná opatření vliv na změnu odtokových poměrů [2]. Nezbytnou součástí ochrany préed přivalovými povodněmi je tedy také komplexní protierozní ochrana půdy [3, 4].

Tabulka 2. Hodnoty CN Il pro opatřeni na orné půdě a hydrologické skupiny půd (HSP) Table 2. Values of CN II for measures on arable land and hydrological soil groups (HSP)

\begin{tabular}{llllll} 
& \multicolumn{1}{l}{ HSP } & & & & \\
\cline { 2 - 6 } Opatření & A & B & C & D & N \\
\hline ochranné zatravnění & 39 & 61 & 74 & 80 & 64 \\
\hline $\begin{array}{l}\text { vyloučení erozně nebezpečných } \\
\text { plodin, použití půdoochranných } \\
\text { technologií }\end{array}$ & 60 & 72 & 80 & 83 & 74 \\
\hline $\begin{array}{l}\text { erozně nebezpečné plodiny } \\
\text { pěstovány půdoochrannými } \\
\text { technologiemi }\end{array}$ & 64 & 74 & 81 & 85 & 76 \\
\hline
\end{tabular}

N... hydrologická skupina půd neurčena

\section{POSOUZENÍ KRITICKÝCH BODU゚ SRÁŽKOODTOKOVÝMI MODELY}

Hodnoty CN posloužily mimo jiné pro výpočet povodňových vln v profilech tzv. kritických bodů, představujících nebezpečí ohrožení intravilánu při prívalových srážkách. V rámci projektu bylo posuzováno celkem 490 kritických bodů v územích kategorie A a B. V potenciálně nejohroženějších povodích kritických bodů byla provedena terénní šetření, významnost kritických bodů byla diskutována s místní samosprávou a byla navržena opatření pro zmírnění možných následků prívalových srážek.

Pro 226 kritických bodů byly sestaveny srážkoodtokové modely v prostředí HEC-HMS. V každém modelu jsou k dispozici výpočty pro stávající stav a návrhový stav řešeného povodí. Při vytváření modelů byla použita metodika podle ČHMÚ $[5,6]$. Výpočet objemu přímého odtoku tedy využívá metodu CN-křivek, transformace prímého odtoku metodu jednotkového hydrogramu podle Clarka a postup povodňové viny v ríčních úsecích metodu Muskingum. Zatížení modelů proběhlo návrhovými dvacetiletými a stoletými srážkami. Vzhledem k hromadnému zpracování nebyly při modelování vyhodnocovány možné nejistoty a neurčitosti.

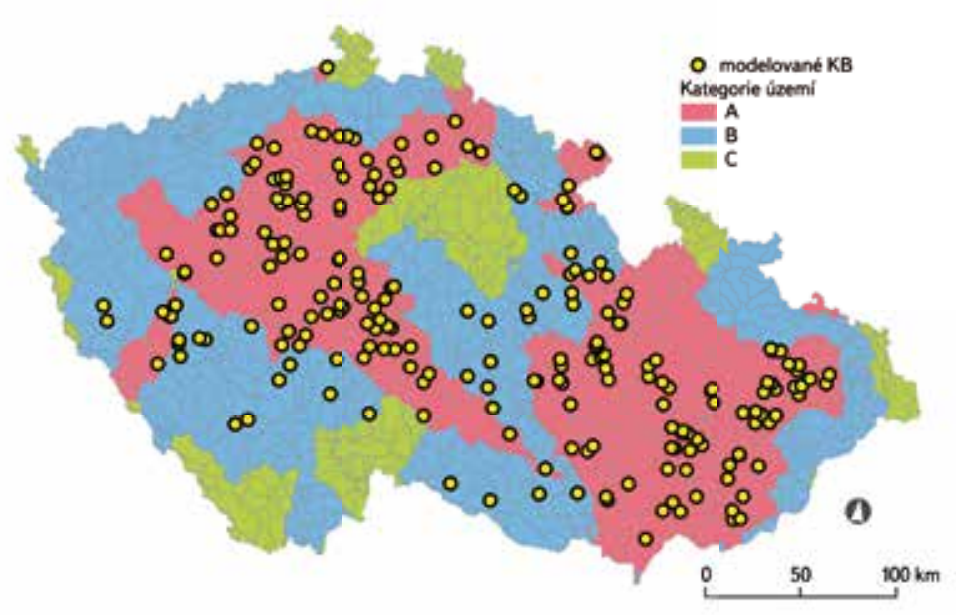

Obr. 2. Modelované profily kritických bodů

Fig. 2. Modeled profiles of critical points

Pro snížení povodňových vln jsou nejúčinnějšími opatřeními vodní nádrže s retenčním prostorem. Nově navrhované nádrže byly do povodí umístovány podle potřeby ochrany zastavěného území, morfologie terénu a využití území. Navržené nádrže s odvozenou charakteristikou výšky hladiny a objemu byly pro účely základní analýzy efektivnosti uvažovány s přelivem, jehož kóta je 0,5 m pod úrovní hladiny při stoleté povodňové vině. Vedle nádrží působí na retenci v povodích příznivětaké protierozní opatřenív ploše povodí (sníženíhodnoty CN) a revitalizace vodních toků, mírně zpomalující průchod povodní (úprava transformačního faktoru $v$ metodě Muskingum).

$\checkmark$ katalogovém listu srážkoodtokového vyhodnocení kritického bodu je mimo jiné znázorněn hyetogram stoleté a dvacetileté srážky. Dále je $v$ grafu možno sledovat hydrogramy stoletého a dvacetiletého odtoku v uzávěrovém profilu kritického bodu $v$ m³/s pro stávající stav a návrhový stav. Další část katalogového listu obsahuje tabelární výčet a vyhodnocení sledovaných veličin pro významné uzly schematizovaného povodí. Sledovanými veličinami jsou plocha povodí $v \mathrm{~km}^{2}$, objem povodňové vlny $v$ tis. $\mathrm{m}^{3}$, kulminační průtok $v \mathrm{~m}^{3} / \mathrm{s}$, maximální zadržený objem $v$ navržených nádržích $v$ tis. $\mathrm{m}^{3}$ a maximální objem nádrží, odpovídající ploše zátopy ( $v$ tis. $\left.\mathrm{m}^{3}\right)$. V pravé části tabulky se nachází vyhodnocení změny kulminace $v$ hodnotách průtoku $\left(\mathrm{m}^{3} / \mathrm{s}\right)$ a v procentuálním vyjádření změny. 


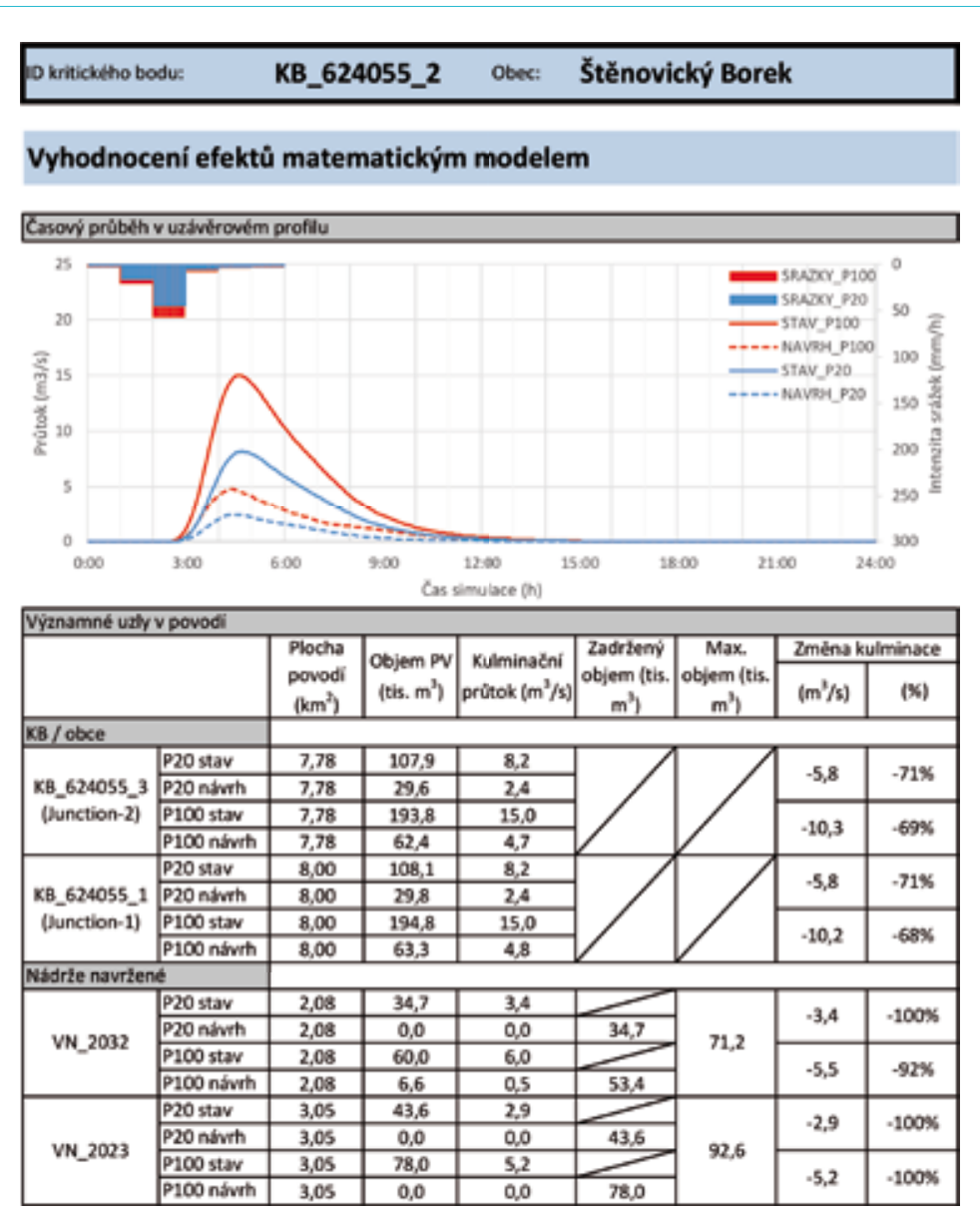

Obr. 3. Vyhodnocení efektů modelem HEC-HMS pro kritický bod v obci Štěnovický Borek Fig. 3. Evaluation of effects by HEC-HMS model for the critical point in Štěnovický Borek municipality

\section{ZÁVĚR}

Uváděné postupy metody CN křivek a srážkoodtokového modelování umožňují posoudit vlivy souboru opatření na odtokové poměry v povodích. Opatření v ploše povodí, opatření na vodních tocích a v nivách i nově navrhované nádrže působí v souhrnu na zlepšení stavu krajiny z hlediska protipovodňového a protierozního i s presahem do ochrany před výskytem sucha.

\section{Literatura}

[1] JANEČEK, M. a KOVÁR̆, P. Aktuálnost „Metody čísel odtokových křivek - CN“ k určování prímého odtoku z malého povodí. Vodníhospodárstvíi/2010, s. 187-190

[2] MŽP. Metodika k navrhováni protipovodňových opatřeni v ploše povodi, které současně řeši obnovu vodního režimu a snižování eroze. 2008, $131 \mathrm{~s}$.

[3] JANEČEK, M. aj. Ochrana zemědělsképưdy pred erozí. ČZU, 2012, $113 \mathrm{~s}$.

[4] NOVOTNÝ, I. aj. Pr̈́ručka ochrany proti vodní erozi. MZe, 2014,73s.

[5] KULASOVÁ, B., ŠERCL, P., BOHAČ, M. aj. Verifikace metod odvozeni hydrologických podkladů pro posuzováni bezpečnosti vodnich děl za povodni, Závěrečná zpráva projektu QD1368. ČHMÚ, 2004, 128 s.

[6] ŠERCL, P. Vliv fyzicko-geografických faktorů na charakteristiky teoretických návrhových povodñovích vln. Sborník prací ČHMÚ, sv. 54, 2009, 88 s.
Autoři

Mgr. Martin Stehlík

凶martin.stehlik@sweco.cz

Ing. Martin Pavel

凶martin.pavel@sweco.cz

Ing. Vladimír Burian

凶vladimir.burian@sweco.cz

Sweco Hydroprojekt a. s.

Př́spěvek prošel lektorským řízením.

PROCESS OF EVALUATION OF RUNOFF CONDITIONS AND DETERMINATION OF DESIGN FLOWS IN THE PROJECT STRATEGY FOR PROTECTION AGAINST THE NEGATIVE IMPACTS OF FLOODS AND EROSION EVENTS BY NATURE-FRIENDLY MEASURES IN THE CZECH REPUBLIC

\section{STEHLIK, M.; PAVEL, M.; BURIAN, V.}

Sweco Hydroprojekt a. s.

Keywords: runoff conditions - runoff curve numbers - critical points reservoirs - rainfall-runoff modeling

Project The Strategy for protection against the negative impacts of floods and erosion events by nature-friendly measures in the Czech Republic comprehensively addresses the possibility of increasing water retention in the landscape. Article in a nutshell describes two of the tools for analysis and design: using the curve number method and rainfall-runoff modeling. 